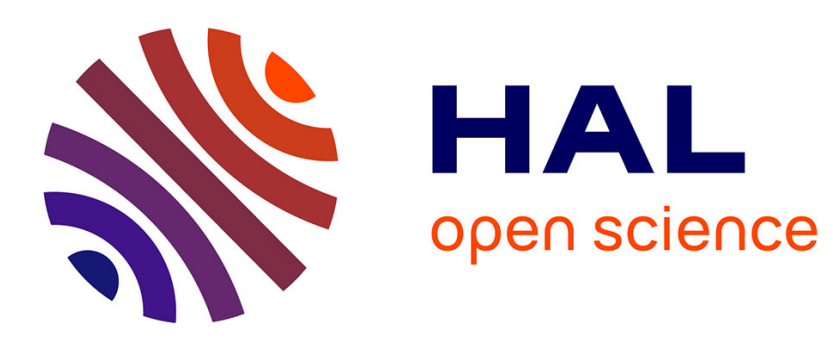

\title{
Oceanic slab melting and mantle metasomatism
}

Bruno Scaillet, Gaëlle Prouteau

\section{- To cite this version:}

Bruno Scaillet, Gaëlle Prouteau. Oceanic slab melting and mantle metasomatism. Science Progress, 2001, 84, pp.335-354. hal-00089820

\section{HAL Id: hal-00089820 \\ https://hal-insu.archives-ouvertes.fr/hal-00089820}

Submitted on 24 Aug 2006

HAL is a multi-disciplinary open access archive for the deposit and dissemination of scientific research documents, whether they are published or not. The documents may come from teaching and research institutions in France or abroad, or from public or private research centers.
L'archive ouverte pluridisciplinaire $\mathbf{H A L}$, est destinée au dépôt et à la diffusion de documents scientifiques de niveau recherche, publiés ou non, émanant des établissements d'enseignement et de recherche français ou étrangers, des laboratoires publics ou privés. 


\title{
Oceanic slab melting and mantle metasomatism
}

\author{
BRUNO SCAILLET1 AND GAËLLE PROUTEAU2 \\ Bruno Scaillet is a CNRS research scientist at the Institut des Sciences de la Terre \\ d’Orléans (ISTO), 1a Rue de la Férollerie, 45071, Orléans, France, since 1993. \\ Gaëlle Prouteau is assistant professor at the Université Pierre et Marie Curie, Laboratoire \\ de Pétrologie, modélisation des matériaux et des processus, 4 place Jussieu, 75 252, \\ Paris, France,
}

Modern plate tectonic brings down oceanic crust along subduction zones where it either dehydrates or melts. Those hydrous fluids or melts migrate into the overlying mantle wedge trigerring its melting which produces arc magmas and thus additional continental crust. Nowadays, melting seems to be restricted to cases of young $(<50 \mathrm{Ma})$ subducted plates. Slab melts are silicic and strongly sodic (trondhjemitic). They are produced at low temperatures $\left(<1000^{\circ} \mathrm{C}\right)$ and under water excess conditions. Their interaction with mantle peridotite produces hydrous metasomatic phases such as amphibole and phlogopite that can be more or less sodium rich. Upon interaction the slab melt becomes less silicic (dacitic to andesitic), and $\mathrm{Mg}, \mathrm{Ni}$ and $\mathrm{Cr}$ richer. Virtually all exposed slab melts display geochemical evidence of ingestion of mantle material. Modern slab melts are thus unlike Archean Trondhjemite-Tonalite-Granodiorite rocks (TTG), which suggests that both types of magmas were generated via different petrogenetic pathways which may imply an Archean tectonic model of crust production different from that of the present-day, subduction-related, one.

\section{Introduction}

Perhaps the best and clear manifestation of plate tectonics is the volcanic activity associated to subduction zones, where cold and dense oceanic plates sink below either continental or oceanic crusts. The most prominent example of such a process is provided nowadays by the Circum Pacific volcanic chain. The process of subduction is a fundamental mechanism that allows the Earth to dissipate its internal energy that arises mostly from heat produced by the radioactive decay of $\mathrm{U}$, Th and $\mathrm{K}$ elements. This mechanism ensures the return toward the deep mantle of cold and old crustal material. It is mass balanced by mantle uprise beneath mid oceanic ridges (MOR) which provides the return of high temperature material toward the surface, closing the convective loop. This large scale convective motion allows the oceanic crust to be recycled at depth where it mixes back with pre-existing mantle rocks, producing a less homogeneous material and imparting first order geochemical signatures to mantle reservoirs, depending on the vigor of the convective process, the depth at which slab settling stops, and the elapsed time since subduction started. Not all the subducted plate returns to the mantle, however. The very presence of arc volcanoes above subduction zones is first order evidence that subduction modifies the thermal structure and the chemical composition of the so-called mantle wedge, ie that part of the mantle that lies on top of the subducting oceanic plate (Figure 1). The amount of slab material involved in this process, as well as its physical nature (hydrous fluid or silicate melt), have been a matter of a continuing debate over the last 40 years. The most popular and conventional scheme 
for producing arc magmas is one whereby an hydrous fluid ingresses into the mantle wedge following the dehydration of the oceanic plate. The slab-derived fluid metasomatises the mantle wedge whose subsequent partial melting yields arc-magmas with their distinctive trace element characteristics relative to MOR basalts, notably their enrichment in large ion lithophile elements (LILE: K, Rb, Ba, Sr, Th, U) and depletion in high field strength elements (HFSE: Nb, Ti, Ta)1. Because the metamorphism of hydrous oceanic basalts yields amphibolite rocks, early experimental phase equilibria performed on oceanic basalt compositions to investigate where $\mathrm{H} 2 \mathrm{O}$ was being released at depth focused on amphibole stability. Such works have shown that amphibole breakdown (the amphibolite-eclogite transition), occurs at 22-25 kbar, that is at depths where the top of the sudbucting plate lies at ca $100 \mathrm{~km}$, thus broadly fitting with the position of most volcanic front arcs in active subduction zones1. More recent works have shown however that, in addition to amphibole, there exists a number of other hydrous phases in metamorphosed hydrous basalts (talc, phengite, epidote), each breaking down under widely different pressures2. As a consequence there is not only a single discontinuous dehydration reaction and thus a single point source for fluid release from the slab, but instead a more or less continuous volatilisation of metamorphic fluids toward the mantle wedge. The near constant position of the volcanic front arc is interpreted to reflect a physical control on magma mobility2 (there is a need to reach a certain amount of partial melting before ascent starts). Fluid-based models have gained wide audience especially in the geochemical community and it is now generally accepted that arc magmas dominantly originate by partial melting of the mantle wedge under the influx of slab fluids, and subsequently fractionate at shallow levels in the crust. The slab contribution needs not be restricted to hydrous fluid release, however. In fact, first proposals for slab involvement in arc magmatism called upon its direct melting rather than dehydration3. While this possibility is still considered a viable one for Archean times4, for more recent times thermal constraints deduced from numerical simulations of the thermal regime in convergent zones seemed to rule out such a mechanism basically because the overal colder mantle, as compared to Archean times, precludes melting of amphibolite/eclogite (metamorphosed basalt) in Mesozoic to present-day subduction settings. Nevertheless, the possibility of slab melting has been resurrected during the last decade on the basis of geochemical arguments by Defant and Drummond5. In this paper, we review recent advances in the field of slab melting as a contributing factor both to arc magmas diversity and to the metasomatism of the sub-arc mantle. We start by briefly reviewing current general concepts about arc magma genesis and consider successively the possibility that dry, dehydration and watersaturated melting of basaltic crust occurs in subduction zones and the broad geochemical implications (mantle metasomatism) associated to each of these scenari. We end by discussing the implications of these results for the genesis of continental crust in Archean times. 


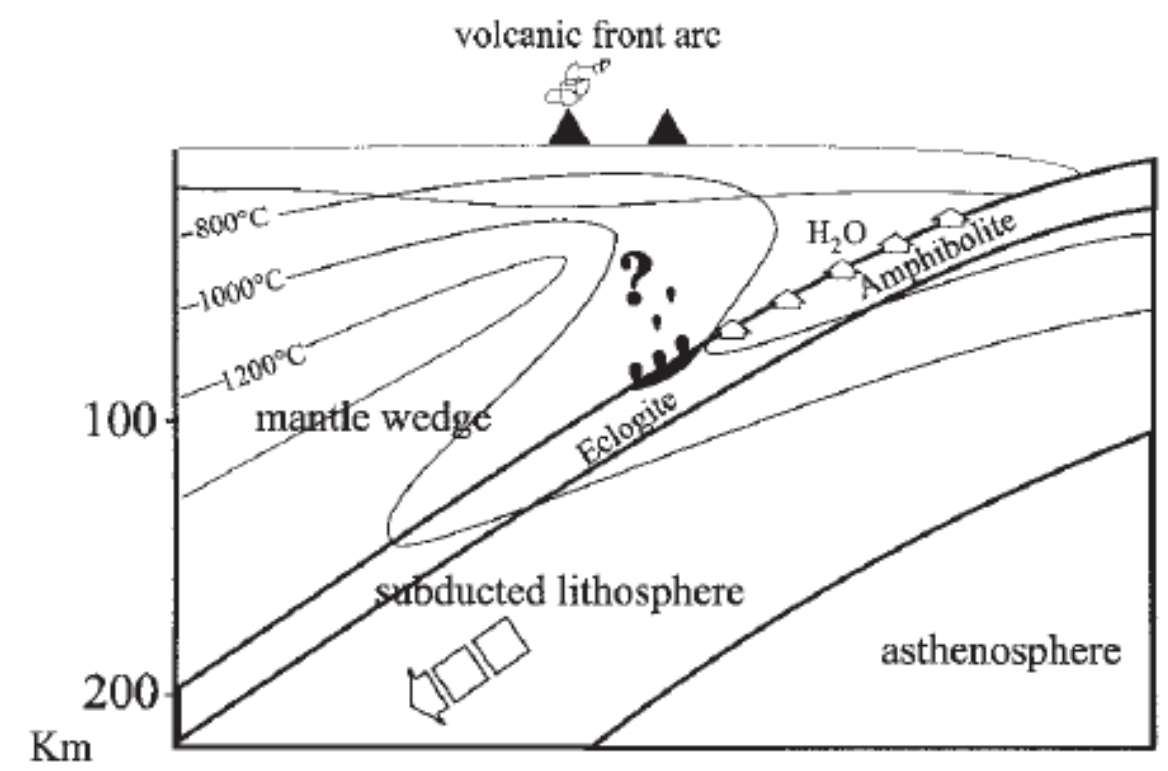

Fig. 1 Generalised cross-section of a modern subduction zone showing the position of the volcanic front arc and the cold finger phenomenon that yields the inversion of geothermal gradient at the base of the mantle wedget,11. Amphibolite and eclogite are metamorphic conditions followed by the top of the descending lithosphere. Dehydration reactions continuously occur along the subduction zone, being controlled by the $\mathrm{P}-\mathrm{T}$ stability of hydrous phases, until conditions favourable to melting are reached, that is temperatures higher than $700-800^{\circ} \mathrm{C}$ above the subducting plate. See text for additional explanations.

\section{Dry melting}

Given that the dominant composition in arc magmas is andesite (57-63 SiO2 in wt\%), experimental studies tested whether such melt could be produced by partial melting of basaltic crust or by melting of the mantle wedge peridotite. The general geochemical characteristics of common andesites, in particular their high $\mathrm{FeO} / \mathrm{MgO}$, low $\mathrm{Ni}$ and $\mathrm{Cr}$ contents, indicate that they cannot be in equilibrium with mantle assemblages6. Only a few andesite occurrences such as in the Setouchi belt in Japan, have major and trace element compositions compatible with an origin by partial melting of the mantle wedge7. For the vast majority of them however, derivation from a basaltic source is required which gives rise to two main possibilities. Either andesites are produced by low-pressure fractionation of basalts originated by partial melting of the sub-arc mantle or they are derived from partial melting of the subducted basaltic crust. The possibility of direct dry melting of the slab in subduction zone settings was early suggested by Coats8 and first tested experimentally by Green and Ringwood3. These authors showed that dry melting of MORB can indeed produce andesite-like liquids. More recently, high alumina basalts (HAB) which are common in intra-oceanic arcs, have also been proposed to originate from the partial melting of oceanic slab9 and this hypothesis has also received some experimental support10. The temperatures required to achieve such liquid compositions are over $1300^{\circ} \mathrm{C}$ at $30 \mathrm{kbar}$ and the residual mineralogy is eclogitic, that is dominated by garnet and clinopyroxene. Garnet strongly incorporates the heavy rare earth elements (HREE) relative to the light ones (LREE) such that any melt coexisting with garnet is strongly depleted in HREE. Magmas equilibrated with an 
eclogitic residue display steep REE patterns (Figure 2). A first problem with the hypothesis of andesite or HAB being originated by dry slab melting is that they almost never display such steep REE patterns which excludes them from being generated from any garnet bearing source rock. A second problem lies in the temperature required to achieve extensive melting of MORB under dry conditions at high pressure (since basalt melting is not eutectic-like, to obtain an andesitic or a basalt liquid composition from a basalt source rock requires high melt fractions and thus high temperatures). Numerical simulations of the thermal regime in subduction zones clearly show the process of cold finger that affects the subducting slab11 (Figure 1). This is due to the fact that the subducted material is much colder than the initial temperature of the mantle wedge and, because the diffusion of heat in rock is very slow, the downdragged cold slab cannot achieve thermal equilibrium rapidly and remains much colder than the overlying mantle as long as subduction is active (the metamorphic expression of such a process is the well known blueschist rocks that are found in a number of fossil subducted complexes such as the Catalina schist in California). As a result, the top of the subducted slab reaches temperatures lower than $1000^{\circ} \mathrm{C}$ at pressure depths of around 20-30 kbar, conditions which are well below the solidus of dry basalts. These chemical and thermal inadequacies made the slab melting hypothesis fall into disgrace for many years and the slab input was considered, and is still, as largely dominated by hydrous fluid originated from the breakdown of hydrous minerals. Given that before subduction the oceanic crust is hydrothermally altered with the consequence of being heavily hydrated, part of this water is transported at depth, which implies that the role of water in producing slab melts needs to be considered.

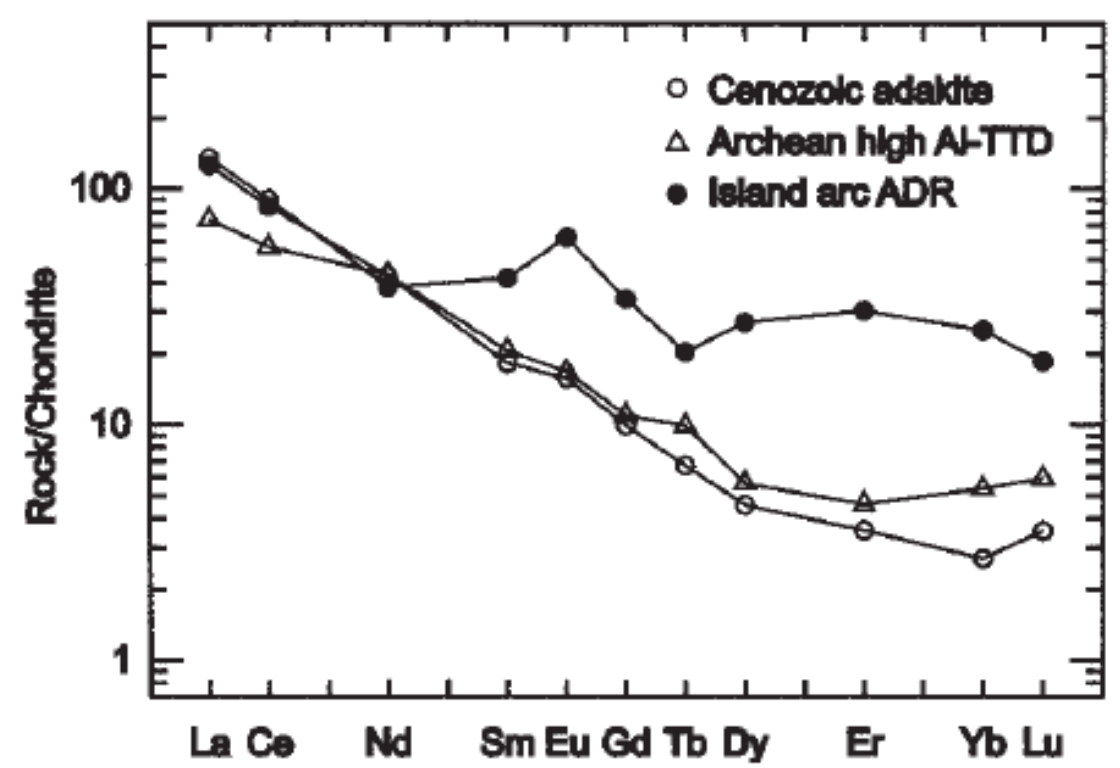

Fig. 2 Typical rare earth element patterns of modern slab melts (adakite), Archean TTG and conventional island arc andesite-dacite-rhyolite seriesss (ADR) including HAB. Whole rocks concentrations are normalised against chondrite (primitive mantle) abundances. Note the steeper attitudes of both adakite and TTG spectra relative to that of ADR suites. This is thought to predominantly reflect the presence of garnet in the melting residue of adakite and TTG source rocks. 


\section{Dehydration melting}

The possibility of slab melting was rejuvenated in the early nineties by Defant and Drummond5 who proposed on geochemical grounds that some modern arc magmas bear evidence of slab melt contribution, sharing some characteristics with the Archean Trondhjemite-Tonalite-Granite (TTG) suites believed to have been also produced by slab melting4. These modern analogues of TTG were termed adakites by Defant and Drummond5 to acknowledge the first clear recognition of such magma type in the Adak island by Kay12. Critical geochemical features include high content in Sr, high Al2O3 and Na2O, low Y and HREE (Yb) (Table 1). Their isotopic signatures in $\mathrm{Sr}, \mathrm{Nd}$ and $\mathrm{Pb}$ are similar to those of MOR basalts. And, in common with all arc magmas, they are depleted in $\mathrm{Nb}, \mathrm{Ti}$, and Ta. Lastly, Cenozoic to modern adakites consistently display low $\mathrm{FeO} / \mathrm{MgO}$ ratios. Erupted adakites are porphyritic (i.e. phenocrystrich), and often rich in hydrous minerals (amphibole, biotite). For those few volcanic adakites studied in some detail, preeruptions conditions are characterised by temperatures lower than $900^{\circ} \mathrm{C}$, and water-rich and oxidizing conditions. The MORB-like isotopic composition of adakites suggests derivation from partial melting of oceanic basalts. Other characteristics are thought to reflect the lack of plagioclase in the residue ( $\mathrm{Sr}, \mathrm{Al} 2 \mathrm{O} 3, \mathrm{Na} 2 \mathrm{O}$ rich) and thus $\mathrm{H} 2 \mathrm{O}$-rich conditions during melting, the presence of garnet (low $\mathrm{Y}$ and $\mathrm{Yb}$ ), and the persistence of ilmenite/rutile and amphibole to buffer $\mathrm{Nb}, \mathrm{Ti}$, and $\mathrm{Ta}$ elements in the melt to low contents. The last characteristic implies low melting temperatures, below $1,000^{\circ} \mathrm{C}$, since higher $\mathrm{T}$ would destabilise amphibole and solubilise much higher amounts of trace elements than those observed, as experimental constraints on the solubility of accessory minerals demand13. On these basis, Defant and Drummond5 proposed that the most likely origin for such magmas was derivation through partial melting of subducted hydrous oceanic crust with the presence of garnet in the residue and with limited sediment contribution at depths. The high MgO content would reflect the limited chemical mantle input during ascent of adakites through the mantle wedge. From a compilation of all occurrences of such a magma type, it was concluded that present day slab melting is limited to arcs where the age of oceanic crust subducted is less than $25 \mathrm{Ma}$. More recent assessment indicates in fact that adakite occurs in arcs with oceanic crust younger than 50 Ma14. Young ages, fast subduction rates are factors both known to increase significantly the thermal gradient along the subducted plate such that melting could theoretically take place before main dehydration reactions start11. The superimposition of geothermal gradients of fast/young subducting plates onto the experimentally derived melting curve for hydrous basalts led Defant and Drummond5 to propose a fertile window for adakite production located at $25 \mathrm{kbar}$ and around $750^{\circ} \mathrm{C}$ (Figure 3). Such cold and water-rich regime for magma genesis is supported by the general cold and H2O-rich pre-eruption status of erupted adakites15. 


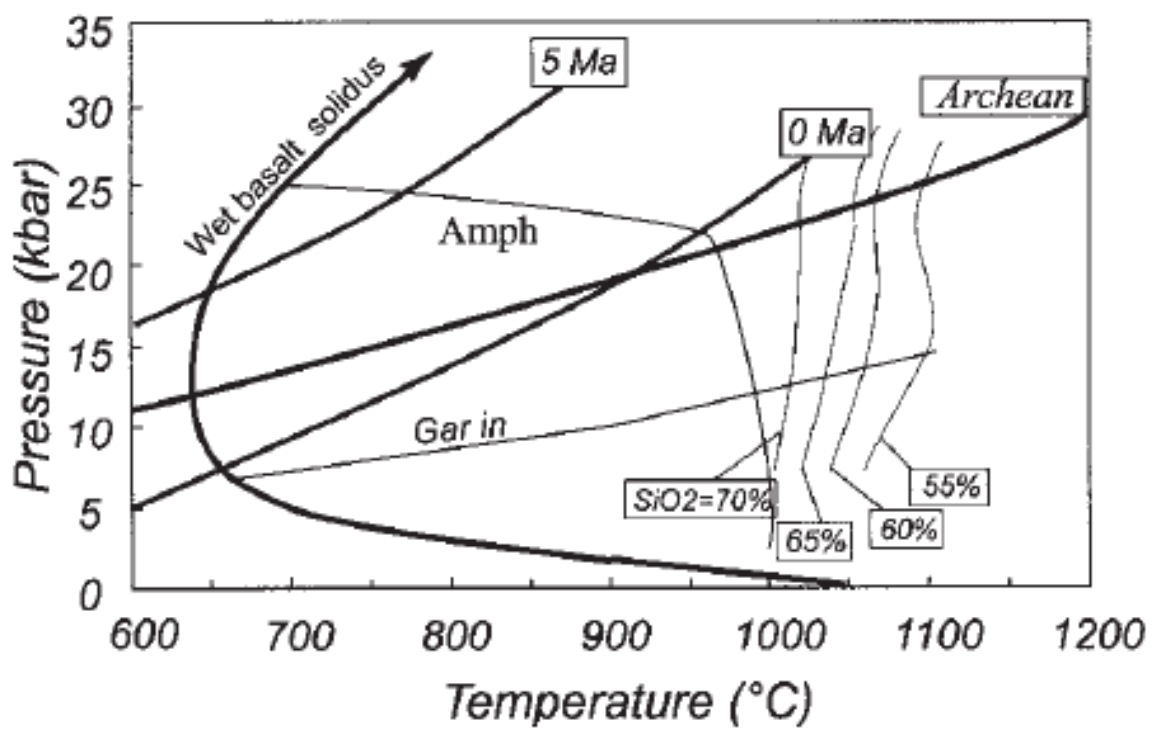

Fig. 3 Pressure-temperature projection showing the locus of the wet basalt solidus and the position of several geothermal gradients calculated for a subducting plate 0 and $5 \mathrm{Ma}$ old as well as that corresponding to Archean conditions11,31. Also shown are the garnet-in curve in basaltic systems, the amphibole stability field and the silica content of melts generated from a dehydration melting reaction of amphibolite rocks (hydrated metamorphosed basalts)17. Note that to produce a dacitic melt from the dehydration melting of a basalt requires temperature in excess of $1,000^{\circ} \mathrm{C}$.

The model of slab melting thus shifted from dry to hydrous conditions, basically reflecting the fundamental role of water in lowering solidus temperatures of upper mantle and crustal rocks. The role of water on the melting behaviour of rocks is not unique, however, in that it ultimately depends on its location within the system being considered. Studies of metamorphic crustal rocks have emphasised that most of the $\mathrm{H} 2 \mathrm{O}$ is stored in hydrous minerals and that there is little evidence for the presence of pervasive free metamorphic fluid in the mid to lower crust16. Application of this finding to subduction zones has led to the concept that water is being carried down through hydrous minerals only and thus its ultimate release depends on the P-T stability of the hydrous mineral. Typically a hydrous mineral can destabilise through either a dehydration or a melting reaction, the latter condition defining the solidus of the rock (under fluidabsent conditions). In the latter hypothesis, i.e. that commonly called dehydration melting reaction, the melting of basalt is thus fixed by the melting of the amphibole it carries. Experimental studies of the dehydration melting of a number of basalts have indeed shown that such a process is capable of producing adakite-like magmas whose major and trace element characteristics broadly match those of their natural counterparts17,18. A problem arises, however, when considering the temperatures needed to produce dacitic or andesitic slab melts from a dehydration melting reaction: they are higher than $1,000^{\circ} \mathrm{C}$, or even over $1,050^{\circ} \mathrm{C}$ (Figure 3), melts obtained at lower temperatures being granitic, that is richer in $\mathrm{K} 2 \mathrm{O}$ and $\mathrm{SiO} 2$ than the average bulk composition of Cenozoic adakites which is dacitic ( $\mathrm{SiO} 2=65 \mathrm{wt} \%$, Table 1 ). Such high temperatures are not recorded by erupted adakites, and according to thermal modelling11, they are highly unlikely to be reached in modern subduction zones where adakites rocks have been documented. In addition, at such high temperatures, slab melts are largely undersaturated with respect to amphibole (by definition since it is its breakdown that produces the liquid) or ilmenite/rutile and thus it becomes 
difficult to explain their depleted character in $\mathrm{Nb}$ and Ta. Finally, high-pressure phase equilibrium of a natural adakite indicate that large amounts of water, in excess of $10 \mathrm{wt} \%$, are needed in order to suppress plagioclase crystallisation up to very shallow levels of magma storage and emplacement, otherwise extensive plagioclase precipation during magma uprise would erase or seriously dampen the characteristic positive $\mathrm{Sr}$ anomaly of adakites since $\mathrm{Sr}$ is strongly partitioned in this mineral. Such high melt water contents are difficult to obtain from a dehydration melting process only because it would require very low melt fractions incompatible with the intermediate bulk rock composition (that is dacitic) of most adakites19. These considerations indicate that the petrogenetic modelling of adakites cannot use the results of dehydration melting experiments. The next and ultimate step to be considered was therefore the role of water as free fluid during melting.

\section{$\mathrm{H}_{2} \mathrm{O}$-saturated melting}

Water can be present in excess of that stored in hydrous minerals and such systems are quoted fluid-present. The solidus temperature is even more depressed relative to that defined by fluid absent conditions. For basaltic compositions, the $\mathrm{H} 2 \mathrm{O}$ saturated solidus lies around $700^{\circ} \mathrm{C}$ at 25 kbar (Figure 3) which is ca $100^{\circ} \mathrm{C}$ lower than the dehydration melting temperature of an amphibolite (ie metamorphosed basalt). Melt compositions produced under such conditions show a great sensitivity to pressure20. When melting is performed within the stability field of amphibole, melts are tonalitic (Table 1), that is notably enriched in $\mathrm{CaO}$ and $\mathrm{Al} 2 \mathrm{O}$, reflecting in large part the instability of plagioclase in the residue. Beyond the stability field of amphibole ( $>25 \mathrm{kbar}$ ), the residue is made of garnet and clinopyroxene \pm ilmenite and the melts are clearly trondhjemitic with a large enrichment in Na2O over both $\mathrm{CaO}$ and $\mathrm{K} 2 \mathrm{O}$ (Table 1). This is due to the fact that part of the sodium that was stored in amphibole cannot be fully balanced by the clinopyroxene and garnet and thus enters the liquid. Conversely, the extensive crystallisation of clinopyroxene buffers the melt $\mathrm{CaO}$ content to low values as does the garnet with $\mathrm{Al} 2 \mathrm{O}$. The critical point of these experiments is that they perfectly reproduce reported occurrences of slab melts found in fossil subduction complexes21 or frozen in metasomatised mantle xenoliths brought upward by typical, that is calc-alcaline, arc lavas22 (Table 1). They also clearly show that the chemistry of slab melts is not constant, in particular its alkali and alkali earth contents can vary with pressure. Depending on the local geothermal gradient, the melting pressure may vary and thus the slab melt composition. Finally they demonstrate that $\mathrm{H} 2 \mathrm{O}$ must be present at depths in amounts in excess of that stored in amphibole. The origin of this free water needs not necessarily be surficial, that is interstitial water carried down from the near surface. Instead, it may come from dehydration of the serpentinite levels underlying the oceanic crust whose melting is trigerred by this continuous influx of water up-section in the slab. The comparison of these experimental or natural genuine slab melts against those erupted5 or preserved as melt inclusions in mantle xenoliths in arc settings 23 shows, however, severe differences in terms of major element compositions, the former being clearly trondhjemitic while the latter are typically dacitic (Table 1), as emphasised above. Such a discrepancy, in particular the less silicic character, may reflect either more extreme melting conditions (i.e. higher temperature of melt production) or that slab melts suffer chemical alteration during ascent through the mantle, or both processes. As pointed out in the introduction, thermal modelling constraints seem to exclude the first possibility for present day conditions. Conversely, given that slab melts must go through a variable but plurikilometric thick layer of mantle rocks before eruption, chemical exchange between slab melt 
and mantle peridotite seems to be an inevitable geochemical consequence for the surficial expression of slab derived magmas.

\section{Mantle metasomatism}

Mantle metasomatism and its counterpart, magma chemical alteration by ultramafic material, have been modelled using various approaches including trace element geochemistry, numerical modelling or experimental interactions at high $\mathrm{T}$ and $\mathrm{P}$. Here we restrict our review to the first order geochemical consequences of such a process, and focus on major element changes that happen when silicic and ultramafic materials are brougth together under upper mantle conditions. Early experimental simulations of deep interaction processes 24 performed between granitic liquids and peridotite showed clearly that the composition of the silicic liquid, although modified, was not dramatically different from the starting one. In particular, the $\mathrm{SiO} 2$ content of the liquid upon interaction did not show a large decrease, as might have been expected from the wide difference in $\mathrm{SiO} 2$ of the two end-member compositions. This illustrates that the interaction cannot be modelled as a simple linear mixing between silicic and ultramafic compositions wheighed by their relative proportions. Subsequent silicic-ultramafic interaction studies using tonalitic compositions have confirmed such a behaviour 25 and emphasised that the dominant reaction is one whereby mantle olivine breaks down into orthopyroxene when interacting with silicic liquids, plus or minus clinopyroxene and garnet, the latter phase depending on the Al2O3rich character of the silicic end member. This reaction prevents the $\mathrm{SiO} 2$ content of the liquid from reaching basaltic values (unless the temperature of interaction is very high $\left(>1,100^{\circ} \mathrm{C}\right)$. When the interacting liquid is trondhjemitic, there is a significant decrease in SiO2 but the liquid still remains dacitic (Table 1). Besides this decrease in $\mathrm{SiO} 2$, the main geochemical features displayed by the reacting liquid are a significant increase in its $\mathrm{Na2O}$ and $\mathrm{MgO}$ contents (Table 1). Silicic to intermediate liquids equilibrated or having reacted with mantle minerals all display lower FeOtot/MgO relative to typical calc-alcaline magmas (when compared at similar $\mathrm{SiO} 2$ contents). This fundamental observation has led some authors to propose that the continental crust, whose average $\mathrm{Fe} / \mathrm{Mg}$ ratio is equally lower, is partly the result of an interaction process with mantle rocks26. The interaction process also affects the modal mineralogy of mantle rocks. Because the silicic melts are hydrous, crystallisation of hydrous minerals such as phlogopite or amphibole are often observed in interaction experiments20, 25, 27, in particular when temperatures are lower than $1,000^{\circ} \mathrm{C}$. As for the melt phase, a characteristic feature of these newly formed minerals (often referred to as metasomatic phases) is their extremely high $\mathrm{MgO}$ content which again reflects the MgO rich nature of the ultramafic material from which they partly grew. The good chemical correspondence between experimentally derived minerals and those analysed in metasomatised peridotites suggests that the latter indeed have suffered an episode of pervasive silicic melt percolation. An additional important observation is that the crystallising metasomatic phases record the more or less alkalirich nature of the invading melt. In particular, phlogopite and amphibole precipitating during trondhjemite-peridotite interaction are sodium-rich20. Given that the sodium-rich character of the metasomatising slab melt is controlled in large part by the pressure at which the subducted oceanic crust melts, the content in $\mathrm{Na}$ of metasomatic phases may be possibly used as a geobarometer for retrieving $\mathrm{P}-\mathrm{T}$ conditions of melting of oceanic crust in fossil subduction zone complexes, at least on a qualitative basis. Thus, mantle metasomatism by slab melt is hardly a cryptic process. Its main mineralogical outcome is 
the crystallisation of hydrous minerals whose composition is testimony of that of their parent melt. A last important feature of such a process is that the experimental data clearly show that interaction does not change the melt content in $\mathrm{Ti}$ (Table 1) which indicates that the depleted character in this element in arc magmas is not due to the interaction mechanism itself. Rather, the metasomatic agent must be depleted before interaction and this in turn indicates that the negative anomaly in $\mathrm{Ti}$ of arc magmas (and possibly $\mathrm{Nb}$ and $\mathrm{Ta}$ ) reflects the direct participation of oceanic crust in their genesis.

Table 1. Experimental and natural slab melts

\begin{tabular}{|c|c|c|c|c|c|c|c|}
\hline & $\begin{array}{l}\text { Cenozoic } \\
\text { adakite }\end{array}$ & $\begin{array}{l}\text { Slab melt } \\
20 \text { kbar } \\
\text { tonalite }\end{array}$ & $\begin{array}{l}\text { Slab melt } \\
30 \mathrm{kbar} \\
\text { trondhjemite }\end{array}$ & $\begin{array}{l}\text { Slab melt } \\
\text { natural } \\
\text { trondhjemite }\end{array}$ & $\begin{array}{l}\text { Slab melt } \\
\text { inclusion in } \\
\text { mantle } \\
\text { olivine }\end{array}$ & $\begin{array}{l}\text { Interacted } \\
\text { trondhjemite }\end{array}$ & $\begin{array}{l}\text { Archean } \\
\text { TTG }\end{array}$ \\
\hline Ref. & 38 & 20 & 20 & 22 & 23 & 20 & 31 \\
\hline $\mathrm{SiO}_{2}$ & 63,8 & 65,5 & 70,8 & 69,1 & 66,7 & 64,3 & 69,9 \\
\hline $\mathrm{TiO}_{2}$ & 0,6 & 0,4 & 0,3 & 0,4 & 0,0 & 0,5 & 0,3 \\
\hline $\mathrm{Al}_{2} \mathrm{O}_{3}$ & 17,4 & 20,9 & 16,1 & 18,3 & 18,4 & 18,8 & 15,6 \\
\hline $\mathrm{FeO}$ & 4,7 & 1,7 & 0,5 & 0,6 & 2,8 & 1,1 & 3,1 \\
\hline $\mathrm{MgO}$ & 2,5 & 0,2 & 0,1 & 0,2 & 0,7 & 1,5 & 1,2 \\
\hline $\mathrm{CaO}$ & 5,2 & 7,0 & 1,4 & 1,1 & 3,3 & 1,0 & 3,2 \\
\hline $\mathrm{Na}_{2} \mathrm{O}$ & 4,4 & 3,7 & 9,3 & 8,1 & 5,5 & 11,4 & 4,9 \\
\hline $\mathrm{K}_{2} \mathrm{O}$ & 1,5 & 0,6 & 1,5 & 2,1 & 2,7 & 1,5 & 1,8 \\
\hline Total & 100 & 100 & 100 & 100 & 100 & 100 & 100 \\
\hline $\mathrm{Ni}$ & 39 & - & - & - & - & - & 14 \\
\hline $\mathrm{Cr}$ & 54 & - & - & - & 45 & - & 29 \\
\hline $\mathrm{Sr}$ & 869 & - & - & - & 762 & - & 454 \\
\hline
\end{tabular}

\section{Preservation and eruption of slab melts}

When the slab melt model was brought back to the front of the scene by Defant and Drummond5, it was based on geochemical analyses of major and trace element compositions of erupted or intruded, pluton sized, rocks. Clearly, however, none of these adakites have major element compositions similar to those obtained from slab melting experiments carried under relevant $\mathrm{P}-$ $\mathrm{T}-\mathrm{H} 2 \mathrm{O}$ conditions. The discovery of melt inclusions in metasomatised mantle xenoliths incorporated in arc lavas with the same major and trace element composition than erupted adakites was taken as direct evidence for an ongoing infiltration of the sub-arc mantle by slab melts23. Yet, the same criticism applies to these melt inclusions, that is their major element composition, though close, does not strictly resemble that obtained in slab melting experiments, being in particular much more potassium-rich (Table 1). The lack of sizeable occurrence of genuine slab magmas in Cenozoic to modern arcs as well as the departure of melt inclusion compositions in sub-arc mantle xenoliths from experimental values, both suggest that preservation of slab melt is not possible nowadays. This may reflect that slab melts represent low 
melt fractions with limited potential for extraction and migration such that most remain trapped at the base of the mantle wedge or even within the subducting crust. It may also reflect that any slab melt produced in the pressure range 20-30 kbar, will have to face a strong chemical barrier when encountering the first layer of the mantle wedge. Specifically, it has been shown that the $\mathrm{SiO} 2$ content of dry liquids equilibrated with mantle minerals increases as the alkali content of the melt increases28. This effect is particularly strong at pressures lower than $20 \mathrm{kbar}$ and the alkali control on the melt $\mathrm{SiO} 2$ content virtually vanishes at a pressure of about at $30 \mathrm{kbar}$, the most likely pressure for melting. Assuming that such an effect persits in hydrous bearing silicic melts, then any slab melt will have little opportunity to overcome this interaction unless the overlying peridotite has been already extensively modified by previous slab melt infiltration such that the ascent path occurs through armoured channels (i.e. extensively metasomatised peridotites). In actual practice, however, on the long-term scale the armouring effect will be limited by the dynamical coupling between the descending lithosphere and the convective overturn of the subarc mantle that continuously provides fresh, unaltered, peridotite material at the locus of slab melting. Therefore, both the physical and chemical factors strongly inhibit preservation and eruption of pristine slab melts. Only in a few rare instances are they preserved such as in paleosubduction complexes21 or caught in the act in rapidly quenched mantle xenoliths22. Hence, the variation in major elements observed in exposed adakites or in melt inclusions with slab melt affinities probably represents various degrees of interaction with mantle material, in particular olivine29 and the more extensive is the interaction the less clear will be the slab melt signature on arc magmas as documented in some arc settings30. In fact, trace element patterns, in particular the REE spectrum, appears to be less sensitive to mantle interaction than do the major elements and they can be possibly used as useful tools for identifying and evaluating the slab melt contribution in the petrogenesis of arc lavas.

\section{Slab melting during the Archean}

Because the melting of oceanic crust in convergent zones produces magmas with distinctive geochemical and petrographical characteristics, these can be, in principle, used as markers of past subduction zones. The Archean TTG are often seen as equivalent of adakites, and as such they have been used as evidence for the operation of modern type large scale horizontal tectonic transport back to Archean times31. TTG occurrences are widespread across Archean terranes which indicate that if they indeed formed through slab melting, such a process was of major importance quite early in Earth's evolution. Specifically, slab melting in arc settings has been proposed as the main mechanism for continental crust production during the first $2.5 \mathrm{Ga}$, after which worldwide silicic magmatism shifted toward more potassium rich varieties, a shift thought to reflect a major and abrupt change of the mechanism of magma production in convergent zones31. As explained in the introduction, the fact that adakite-type magma is a very subordinate one in modern settings is primarily due to the overall cooling of the Earth which hardly allows melting conditions to be reached along the Benioff zone. Conversely, according to Martin4, hotter conditions in the Archean allowed more frequent, perhaps systematic, interception of melting conditions of the subducted slab. However, this general scheme has been recently disputed32, on the basis that the major element compositions of TTG display significant differences with modern adakites, excluding the so-called sanukitoids which are late Archean mantle-derived but volumetrically minor high-Mg andesites31. A comparison of average TTG 
and adakite compositions shows indeed that TTG are more silicic and have higher $\mathrm{FeO} / \mathrm{MgO}$ and lower $\mathrm{Ni}$ and $\mathrm{Cr}$ than adakites (Table 1). The last three parameters indicate that TTG have been less contaminated by mantle interaction than typical Cenozoic adakites. As pointed out by Smithies32, this is hardly reconcilable with a modern subduction zone geometry, where any slab melt must rise through mantle peridotite. The higher temperatures prevailing in Archean times should have favored chemical exchange between silicic and ultramafic rocks. This higher temperature condition in the mantle holds also for slab melt production4. Both factors suggest that Archean TTG should be on average more mafic than their modern counterpart, but the reverse is observed. An additional problem arises when considering our understanding for present slab melting conditions. The available evidence summarised above call for melting with excess $\mathrm{H} 2 \mathrm{O}$. There is no reason to believe that such a condition did not equally apply in Archean times. Given that geothermal gradients were higher, the melting of subducted oceanic crust would occur at shallower levels and higher temperatures. Under these conditions (lower $\mathrm{P}$, higher $\mathrm{T}$ and high $\mathrm{H} 2 \mathrm{O}$ ), experimental evidence dictate that slab melting would dominantly yield tonalitic melts20 and not trondhjemites as observed (Table 1). These observations suggest that either modern type plate tectonics existed in the Archean but with a very peculiar geometry of subduction that avoided protracted mantle interaction (e.g. very flat subduction style without mantle wedge) or that the mechanism of TTG production was different from that of adakite, in which case TTG and adakites have not the same geodynamic significance. The commonly proposed alternative for TTG genesis, but also for some modern adakite-type magmas34, is by dehydration melting in the stability field of garnet of basaltic lower crust in response to basalt underplating. In fact, whatever the tectonic model proposed35 (oceanic plateau accretion, stacking/obduction of oceanic crust), all alternatives to modern subduction zones for producing TTG have called upon dehydration melting of basalt protoliths. This requires basalt protoliths to be partly hydrated prior to melting31 and thus that water was brought to that depth in a way so efficient that the lower Archean crust was made predominantly of amphibolite whose widespread melting generated the voluminous TTG. Insofar as the only clearly recognised mechanism to bring water at depth on a global scale is by subduction of oceanic crust altered by sea water, it follows that TTG production may require in some way the operation of subduction type tectonic, although they may not be strictly related to it. TTG and adakites could thus be mere petrogenetic variations on the same theme that need not necessarily to be opposed to each other.

\section{Conclusions}

This brief overview gives our present knowledge about melt input from the subducted oceanic crust. Although not decisive, the inspection of major element compositions appears to place broad constraints on the process of slab melting and in particular onto the physical conditions during melting. Available natural and experimental data show that modern genuine slab melts are trondhjemitic, not andesitic or dacitic, and that the composition of exposed adakites is largely controlled or affected by interaction with mantle material. In this respect, modern slab melts are unlike Archean TTG. Generally, only the by-product of the interaction process, that is the metasomatic phases, will be left over such as in some Alpine ophiolite complexes36. Melting of such metasomatised peridotites will give rise to arc magmas that preserve part of the slab melt chemical imprints since the metasomatic phases will be among the first ones to participate to any subsequent melting event. Still, despite that our general understanding has made large progress 
during the past decade, the contribution of oceanic crust to arc magmatism is far from being well constrained. From the experimental standpoint three critical aspects need additional assessment. The first concerns the possibility of having a compositional continuum between hydrous fluids and hydrous silicate melts at depth. This possibility has been raised by the experimental work of Bureau and Keppler37 amongst others on various analog rock melt compositions which suggests that at mantle pressures, most magma-H2O systems are above their critical point beyond which the fluid and hydrous silicate melts merge into a single phase. If this were true, then the concept of solidus no more holds in the deeper part of the sub-arc mantle and in the subducting oceanic plate as well and there would be no need to try distinguish between fluid or melt dominated regimes. It remains, however, that all previous melting studies carried out on basalt- $\mathrm{H} 2 \mathrm{O}$ or peridotite-H2O systems have been able to define precisely a solidus curve up to a pressure of about 90 kbar2. In addition, experiments aimed at constraining partition coefficients between fluid and minerals and between melt and minerals at mantle pressures have found significant differences between the two data sets. These experimental observations suggest that there is still room for the solidus concept in subduction zones. The second aspect concerns our understanding of the melting behaviour of the oceanic crust, in particular the determination of how melt composition varies with the depth and temperature of melting when excess water is present. The number of modern data in this field is exceedingly low, most experimental studies being restricted to the sub-solidus behavior of the subducted oceanic crust. Although this might appear surprising, it partly reflects the preponderance of the fluid-based model in geochemical treatments of the involvement of oceanic crust in recent arc magmas that have implicitly guided experimental studies toward this field. The third point deals with the interaction process between silicic melts and peridotite, an issue that depends on the previous one. There is a clear need for more systematic studies that vary both the silicic melt and ultramafic rock compositions as well as the P-T conditions of interaction. In particular, the behavior of trace elements during such processes demands a more rigorous assessment if we are to use trace element geochemistry as a petrogenetic tool in arc settings.

\section{References}

1. Tatsumi, Y \& Eggins, S. (1995). Subduction zone magmatism. Frontiers in Earth Sciences, Blackwell Science, pp. 205.

2. Schmidt, M. \& Poli, S. (1998) Experimentally based water budget for dehydrating slabs and consequences for arc magma generation, Earth Planet. Sci. Lett. 163, 361-379.

3. Green, T.H. \& Ringwood, A.E. (1968) Genesis of calc-alkaline igneous rock suite. Contrib. Mineral. Petrol., 18, 105-162.

4. Martin, H., (1986) Effect of steeper Archean geothermal gradient on geochemistry of subduction zone magmas, Geology 14, 753-756.

5. Defant, M.J. \& Drummond, M.S. (1990) Derivation of some modern arc magmas by melting of young subducted lithosphere, Nature 347, 662-665.

6. Gill, J.B. (1981) Orogenic andesites and plate tectonics. New York, Springer Verlag, 390 p.

7. Tatsumi, Y. (1982) Origin of high-magnesian andesites in the Setouchi volcanic belt, southwest Japan, II. Melting phase relations at high pressures. Earth Planet. Sci. Lett., 60, 305317. 
8. Coats, R.R. (1962) Magma type and crustal structure in the Aleutian arc. In Crust of the Pacific basin. Geophys. Mon. Am Geophys. Union, 6, 92-109.

9. Brophy, J.G. \& Marsh, B.D. (1986) On the origin of high alumina arc basalts and the mechanics of melt extraction. J. Petrol. , 27, 763-789.

10. Johnston, A.D. (1986) Anhydrous P-T relations of near-primary high alumina basalt from the South Sandwich Islands. Implications for the origin of island arcs and tonalite trondhjemite series rocks. Contrib. Mineral. Petrol., 92, 368-382.

11. Peacock, S.M., Rushmer, T. \& Thompson, A.B. (1994) Partial melting of subducting oceanic crust, Earth Planet. Sci. Lett. 121, 227-244.

12. Kay, R. W. (1978) Aleutian magnesian andesites: melt from subducted Pacific ocean crust. J. Volc. Geotherm. Res., 4, 117-132

13. Ryerson, F.J. \& Watson, E.B. (1987) Rutile saturation in magmas: implications for Ti-Nb-Ta depletion in island-arc basalts, Earth Planet. Sci. Lett. 86, 225-239.

14. Juteau, T. \& Maury, R. (1998). Géologie de la croûte océanique. Pétrologie et dynamique endogène. Masson, Paris, 367 p.

15. Scaillet, B. \& Evans, B.W. (1999) The June 15, 1991 eruption of Mount Pinatubo. Phase equilibria and pre-eruption conditions P-T-fO2-fH2O of the dacite magma. J. Petrol., 40, 381411.

16. Clemens, J.D. \& Watkins, J.M. (2001) The fluid regime of high-temperature metamorphism during granitoid magma genesis. Contrib. Mineral. Petrol., 140, 600-606.

17. Rapp, R.P. \& Watson, E.B. (1995) Dehydration melting of metabasalt at 8-32 kbar: implications for continental growth and crust-mantle recycling, J. Petrol. 36, 891-931.

18. Sen, C. \& Dunn, T.(1994) Dehydration melting of a basaltic composition amphibolite at 1.5 and 2.0 GPa: implications for the origin of adakites, Contrib. Mineral. Petrol. 117, 394-409.

19. Prouteau, G., Scaillet, B., Pichavant, M. \& Maury, R.C. (1999) Fluid-present melting of ocean crust in subduction zones, Geology 27, 1111-1114.

20. Prouteau, G., Scaillet, B., Pichavant, M. \& Maury, R.C. (2001) Evidence for mantle metasomatism of hydrous silicic melts derived from subucted oceanic crust. Nature, 410, 197200.

21. Sorensen, S.S. \& Grossman, J.N. (1989) Enrichment of trace elements in garnet amphibolites from a paleo-subduction zone: Catalina Schist, southern California, Geochim. Cosmochim. Acta 53, 3155-3177.

22. Kepezhinskas, P.K., Defant, M.J. \& Drummond, M.S. (1995) Na metasomatism in the islandarc mantle by slab melt-peridotite interaction: evidence from mantle xenoliths in the north Kamchatka arc, J. Petrol. 36, 1505-1527.

23. Schiano, P., Clocchiatti, R., Shimizu, N., Maury, R.C., Jochum, K.P. \& Hofmann, A. (1995) Hydrous, silica-rich melts in the sub-arc mantle and their relationship with erupted arc-lavas, Nature 377, 595-600.

24. Sekine, T. \& Wyllie, P.J. (1983) Experimental simulation of mantle hybridization in subduction zones. J. Geol., 91, 511-528.

25. Carroll, M.J. \& Wyllie, P.J. (1989) Experimental phase relations in the system peridotitetonalite-H2O at 15 kbar: implications for assimilation and differentiation processes at the crustmantle boundary, J. Petrol. 30, 1351-1382.

26. Kelemen, P. (1995) Genesis of high Mg\# andesites and the continental crust. Contrib. Mineral. Petrol., 120, 1-19.

27. Sen, C. \& Dunn, T. (1994) Experimental modal metasomatism of a spinel lherzolite and the production of amphibole-bearing peridotite. Contrib. Mineral. Petrol., 119, 422-432. 
28. Hirschmann, M.M., Baker, M.B. \& Stolper, E.M. (1998) The effect of alkalis on the silica content of mantle-derived melts, Geochim. Cosmochim. Acta 62, 883-902.

29. Yogodzinsky, G.M. \& Kelemen, P. (1998) Slab melting in the Aleutians: implications of an ion probe study on clinopyroxene in primitive adakite and basalt. Earth Planet. Sci. Lett., 158, 53-65.

30. Yogodinzski, G.M., Volynets, O.N., Koloskov, A.V., Seliverstov, N.I. (1994) Magnesian andesites and the subduction component in a strongly calcalkaline series at Piip volcano, far western Aleutian, J. Petrol. 34, 163-204.

31. Martin, H. (1994) The Archean grey gneisses and the genesis of continental crust. In Archean crustal evolution, K Condie (ed.). Amsterdam, Elsevier, 205-259.

32. Smithies, R.H. (2000) The Archaean tonalite-trondhjemite-granodiorite (TTG) series is not an analogue of Cenozoic adakite. Earth Planet. Sci. Lett., 182, 115-125.

34. Atherton, M.P. \& Petford, N. (1993) Generation of sodium-rich magmas from newly underplated basaltic crust, Nature 362, 144-146

35. Smithies, R.H. \& Champion, D.C. (2000) The Archaean high-Mg diorite suite: links to tonalite-trondhjemite-granodiorite magmatism and implications for early Archaean crustal growth. J. Petrol., 41, 1653-1671.

36. Zanetti, A., Mazzucchelli, Rivalenti, G. \& Vannucci, R. (1999) The Finero phlogopiteperidotite massif: an example of subduction-related metasomatism, Contrib. Mineral. Petrol. 134, 107-122.

37. Bureau, H. \& Keppler, H. (1999) Complete miscibility between silicate melts and hydrous fluids in the upper mantle: experimental evidence and geochemical implications. Earth Planet. Sci. Lett., 165, 187-196.

38. Drummond, M.S., Defant, M.J. \& Kepezhinskas, P.K. (1996) Petrogenesis of slab derivedtonalite-dacite adakite magmas. Trans. Roy. Soc. Edinburgh, 58, 205-215.

\section{Glossary}

Amphibole: hydrous ferro-magnesian silicate mineral, which can store up to $2 \mathrm{wt} \% \mathrm{H} 2 \mathrm{O}$ in its structure. Amphibole is one of the main H2O-reservoir of mantle rocks. Its presence is often taken as direct evidence for a metasomatism phase having affected the mantle rock.

Andesite: volcanic rock that has between 57 and $63 \mathrm{wt} \% \mathrm{SiO} 2$ and which forms the dominant magma type in most modern arc-settings.

Arc magma: magma produced where tectonic plates converge, such that one plate, usually the denser one, subducts (or is underthrusted) below the other. Because such locations often display large curvatures in map view, the associated magmas are termed arc-magmas.

Archean: geologic period that covers the beginning of Earth (4,500 Ma) up to 2,500 Ma and during which part of the continental crust was created through the massive production of TTGtype magmas.

Basalt: volcanic rock having between 45 and $53 \mathrm{wt} \% \mathrm{SiO}$. 
Calc-alcaline: arc magmas are also often termed calc-alcaline which stresses the fact that they are usually rich in alkalis and alkali-earth elements.

Cenozoic: geologic period whose beginning is fixed at $65 \mathrm{Ma}$ and ends at $2 \mathrm{Ma}$

Dacite: volcanic rocks in arc setting having between 63 and $68 \mathrm{wt} \% \mathrm{SiO} 2$.

Eclogite: any rock having a basaltic composition and whose mineralogy is dominated by a clinopyroxene-garnet assemblage. Usually this happens when basaltic rocks are dragged to pressures in excess of $20 \mathrm{kbar}$ along subduction zones.

Garnet: aluminium rich ferro-magnesian silicate mineral that replaces the plagioclase feldspar at high pressure in most mantle or crustal rocks.

Magma: a mixture of melt(s), crystal(s) and fluid in all proportions.

Metasomatism: process which leads to a solid state alteration of either the mineralogy or geochemistry of any given rock. The metasomatic agent can be either a fluid or a melt.

Olivine: a ferro-magnesian silicate mineral that constitutes most of the mantle.

Peridotite: the dominant type of rock found in the mantle and whose mineralogy is dominated by olivine, the other major minerals being pyroxenes.

Petrogenesis: the identification and quantification of the mechanisms through which any given magma is produced.

Phenocryst: a crystal in a magmatic rock that has crystallised from the magma, as opposed to a xenocryst which has a foreign origin.

Phlogopite: hydrous and potassic ferromagnesian alumino-silicate mineral, which can store up to $4-5 \mathrm{wt} \% \mathrm{H} 2 \mathrm{O}$ in its framework. It is, together with amphibole, the main mineralogical signature of metasomatism in mantle rocks.

Plagioclase: one of the most abundant mineral in magmatic rocks which stores most of the sodium, calcium and aluminium of the rock.

Pluton: any sizeable magma body that does not reach the surface and crystallises at depth.

Porphyritic: term given to any plutonic or volcanic rock bearing large crystals $(>1 \mathrm{~cm})$ which may or may not have crystallised from the rock.

Serpentinite: serpentine is the most common alteration product of olivine which breaks down into serpentine by secondary hydration. Serpentinite are deeply altered mantle rocks commonly found in oceanic basins where the hydrothermal alteration of the oceanic crust by seawater circulation has been pervasive. 
Silicic magma: magma rich in silica. Usually those having more than $60 \mathrm{wt} \% \mathrm{SiO} 2$ are coined silicic magmas.

TTG: acronym for the Trondhjemite-Tonalite-Granodiorite association mostly found in Archean terranes, and believed to have been produced by partial melting of basaltic crust.

Tonalite: a silicic magma richer in calcium relative to both sodium and potassium.

Trondhjemitic, sodic magma: a silicic magma with more sodium than either calcium or potassium.

Ultramafic: a magmatic rock having less than $45 \% \mathrm{SiO} 2$.

Xenolith: any piece of rock or mineral carried by a magma that has not crystallised from it. The most common xenoliths found in magmas are those coming from the terranes that the magma has intruded during its progression toward the surface. 